\title{
Extracting tin from simulated leaching solution of anode slime with cyclone electrowinning method
}

\author{
W. Wang ${ }^{1}$, Zh. Xu' ${ }^{1}$, S. T. Huang ${ }^{1}$, L. M. Yang ${ }^{1}$, Zh. G. Ji ${ }^{1} \& Y . \mathrm{Li}^{1}$ \\ ${ }^{1}$ General Research Institute for Nonferrous Metals,No.2 Xinjiekuowai Street, Beijing, China 100088
}

KEYWORDS: Anode slime, Tin, Cyclone Electrowinning, Current efficiency

ABSTRACT: Simulated leaching solution of tin anode slime was prepared as electrolyte to investigate the performance of cyclone electrowinning on extraction of tin from solution in this work. The results showed that Sn(II) could be extracted as sponge tin with cyclone electrowinning. $\mathrm{Sn}$ (IV) could be extracted as tin plate. As the concentration of tin chloride solution was lower, the current efficiency was lower and the quality of electrolytic product was poorer. On the condition of $\mathrm{Sn}(\mathrm{IV})$ concentration of $50 \mathrm{~g} / \mathrm{L}$, operation time of $2 \mathrm{~h}$, flow flux of $200 \mathrm{~L} / \mathrm{h}$ and current density of $400 \mathrm{~A} / \mathrm{m}^{2}$, the current efficiency was more than $90 \%$ and the electrolytic product was of high purity which contains $99.5 \%$ tin. Cyclone electrowinning was proved to be an effective way to extract Tin from simulated leaching solution.

\section{INTRODUCTION}

Tin is an important strategic resource and has a wide range of applications in industry. Tin recovery from by-product is meaningful for saving resource. Anode slime of tin is a kind of insolubility slime attached on the surface of the anode scrap or precipitated in the bottom of electrolytic bath. The anode slime has high content of tin. Pyrometallurgy process is the common way to recover tin from anode slime ${ }^{[1]}$. Hydrometallurgical processing is another way to extract tin using acid or alkali leaching ${ }^{[2-5]}$. But the further recovery of metals from leaching liquid is also a problem. Cyclone electrowinning is an effective way to recover heavy metals and precious metals from leaching liquid. Many scholars did works on the recovery of metals with cyclone electrowinning ${ }^{[6-10]}$.

In this work, hydrochloric acid was used as leaching agent to extract tin from anode slime first. Tin is leached in the condition of $4 \mathrm{~mol} / \mathrm{L} \mathrm{HCl}$ and 120 minutes using liquid to solid ratio of $6: 1$ at $80^{\circ} \mathrm{Cand} 350 \mathrm{rpm}$, the leaching rates of tin reaches $96.24 \%$. After purification, cyclone electrowinning was applied to recover tin from solution.

\section{MATERIALS AND METHOD}

\section{Materials}

Simulated leaching solution contains $\mathrm{Sn}(\mathrm{II})$ or $\mathrm{Sn}(\mathrm{IV})$. The solution was prepared with $\mathrm{SnCl}_{2} \cdot 2 \mathrm{H}_{2} \mathrm{O}$, $\mathrm{SnCl}_{4}, \mathrm{HCl}$ and deionized water.

Table 1.Chemical composition of simulated leaching solution

\begin{tabular}{lcc}
\hline Components & $\mathrm{Sn}$ & $\mathrm{HCl}$ \\
\hline Content $(\mathrm{g} / \mathrm{L})$ & 25 & 73 \\
\hline
\end{tabular}

\section{Method}

A certain concentration of $\mathrm{Sn}(\mathrm{II})$ or $\mathrm{Sn}(\mathrm{IV})$ chloride solution was prepared as raw material. The opeartion time of cyclone electrowinning was 10 minutes. The product cyclone electrowinning can be collected and tested (the product was analyzed by SEM). 


\section{RESULTS AND DISCUSSION}

\section{Sn(II) solution}

Cyclone electrowinning were carried out with $\mathrm{Sn}(\mathrm{II})$ solution as feed in order to investigate the behaviors of cyclone electrowinning . The condition was set as follows: $25 \mathrm{~g} / \mathrm{L} \mathrm{Sn}$ (II), flow flux of $500 \mathrm{~L} / \mathrm{h}$ and current density of $400 \mathrm{~A} / \mathrm{m} 2$. Figure1 shows the change of cell voltage with operation time. Figure 2. shows SEM image of electrolysis product.

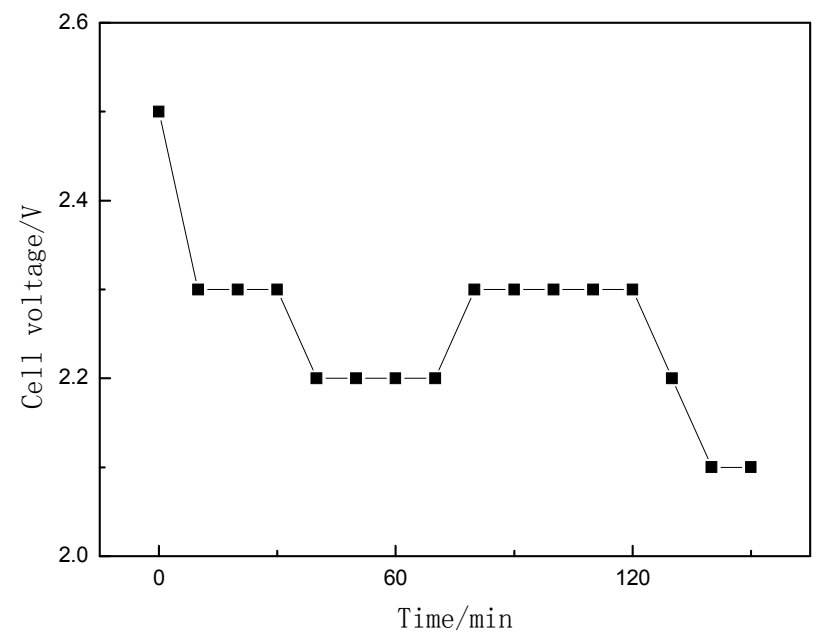

Figure 1. Change of cell voltages with operation time

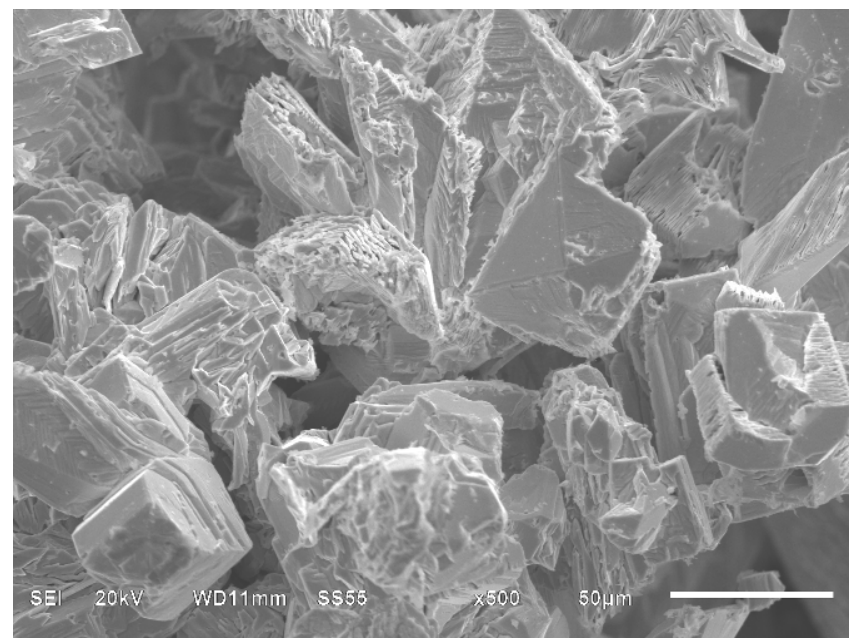

Figure 2. SEM image of electrolytic product

As shown in Figure 1 and Figure 2, cell voltages is lower and lower with the growth of operating time. The cell voltages is not stable so that the electrolytic product is sponge tin. The quality could not be improved through adjusting electrolytic condition. .

\section{Sn(IV) solution}

The cyclone electrowinning tests of $\operatorname{Sn}(\mathrm{IV})$ solution were carried out in order to investigate the cyclone electrowinning behaviors. Figure 3 shows the cell voltage change with the operation time. Figure $4 \sim 6$ show the effect of current density variation, time variation and $\mathrm{Sn}(\mathrm{IV})$ concentration on the current efficiency. 


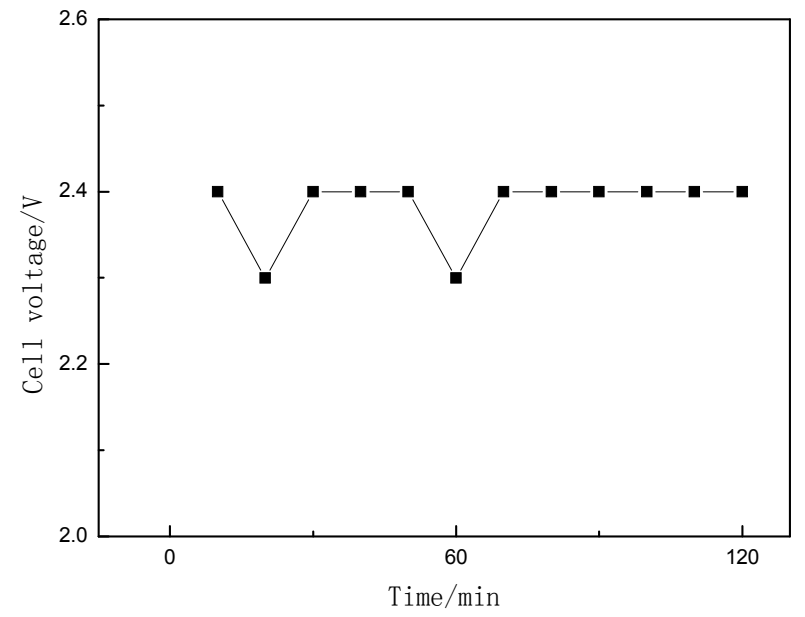

Figure 3. Change of cell voltages with operation time

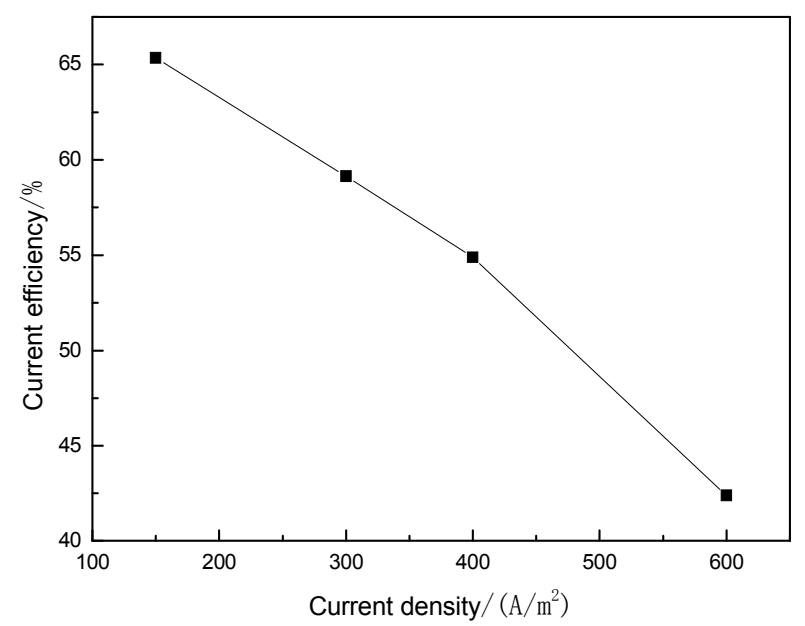

Figure 4. Effect of current density variation on the current efficiency ( $\mathrm{Sn}(\mathrm{IV})$ concentration $25 \mathrm{~g} / \mathrm{L}$, operation time $2 \mathrm{~h}$ and flow flux $200 \mathrm{~L} / \mathrm{h}$ )

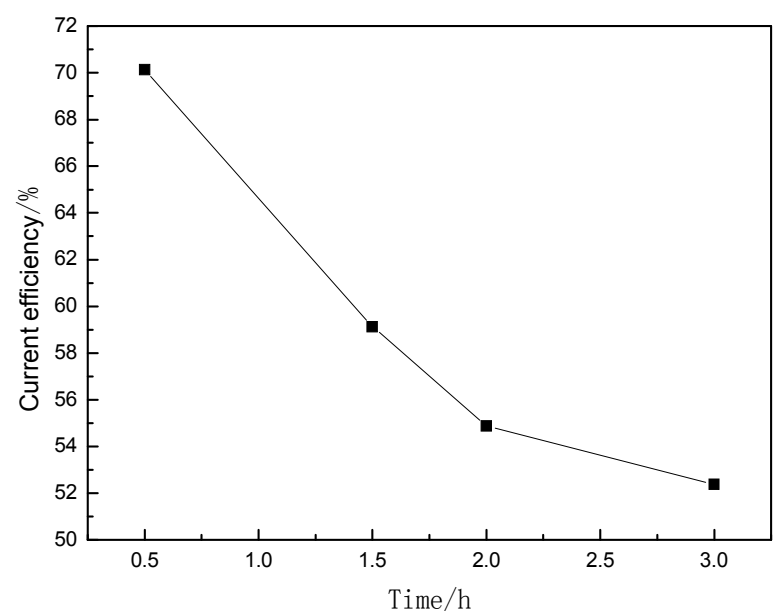

Figure 5. Effect of time variation in $25 \mathrm{~g} / \mathrm{L} \mathrm{Sn}(\mathrm{IV})$ with flow flux $200 \mathrm{~L} / \mathrm{h}$ by using current density $400 \mathrm{~A} / \mathrm{m}^{2}$ 


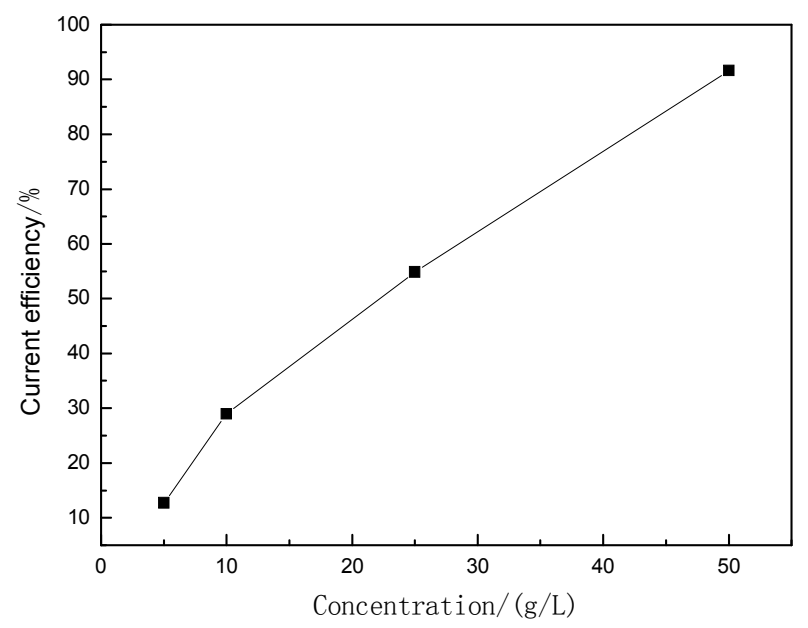

Figure 6. Effect of $\mathrm{Sn}(\mathrm{IV})$ concentration variation in $2 \mathrm{~h}$ with flow flux $200 \mathrm{~L} / \mathrm{h}$ by using current density $400 \mathrm{~A} / \mathrm{m} 2$.

As shown in Figure 3, cell voltages is stable as the operating time growing. It may be the reason why the quality of the electrolytic product is good.

Figure 4 shows that the current density for extracting tin is found to be $400 \mathrm{~A} / \mathrm{m}^{2}$. However, the highest current efficency appears at the lowest current density. The reason why we chooses 400 $\mathrm{A} / \mathrm{m}^{2}$ is to keep the balance between current density and time.

As shown in Figure 5, the optimum time is $2 \mathrm{~h}$. In this conditon, more electrolytic product can be gotten. .

As presented in Figure 6, Sn(IV) concentration variation is an important issue to extract tin. high current efficency can be reached at a high $\mathrm{Sn}(\mathrm{IV})$ concentration. When the $\mathrm{Sn}(\mathrm{IV})$ concentration is more than $50 \mathrm{~g} / \mathrm{L}$, the current efficiency is more than $90 \%$. The electrolytic product was of high purity which contains $99.5 \%$ tin.

Figure 7 9 show the photo and SEM images of electrolytic product.

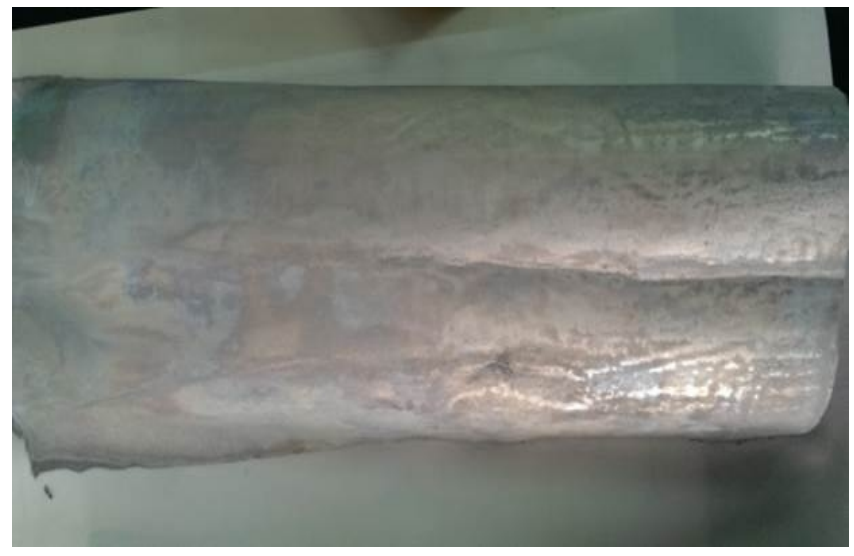

Figure 7. Photo of electrolytic product in the condition of $50 \mathrm{~g} / \mathrm{L} \mathrm{Sn}(\mathrm{IV})$ ion and $2 \mathrm{~h}$ with flow flux $200 \mathrm{~L} / \mathrm{h}$ by using current density $400 \mathrm{~A} / \mathrm{m}^{2}$ 


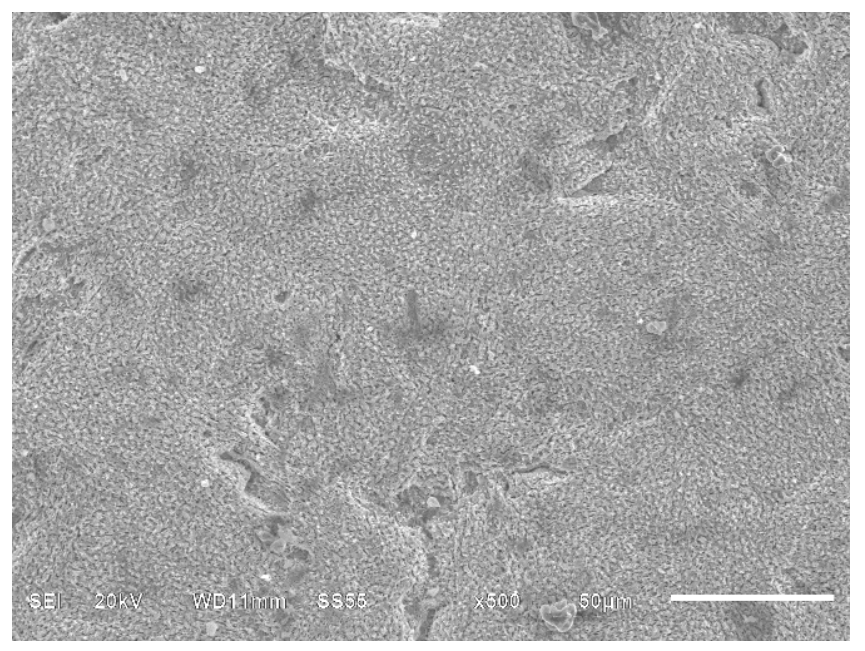

Figure 8. SEM images of electrolytic product in the condition of $50 \mathrm{~g} / \mathrm{L} \mathrm{Sn}(\mathrm{IV})$ ion and $2 \mathrm{~h}$ with flow flux $200 \mathrm{~L} / \mathrm{h}$ by using current density $400 \mathrm{~A} / \mathrm{m}^{2}$ (front of electrolytic product)

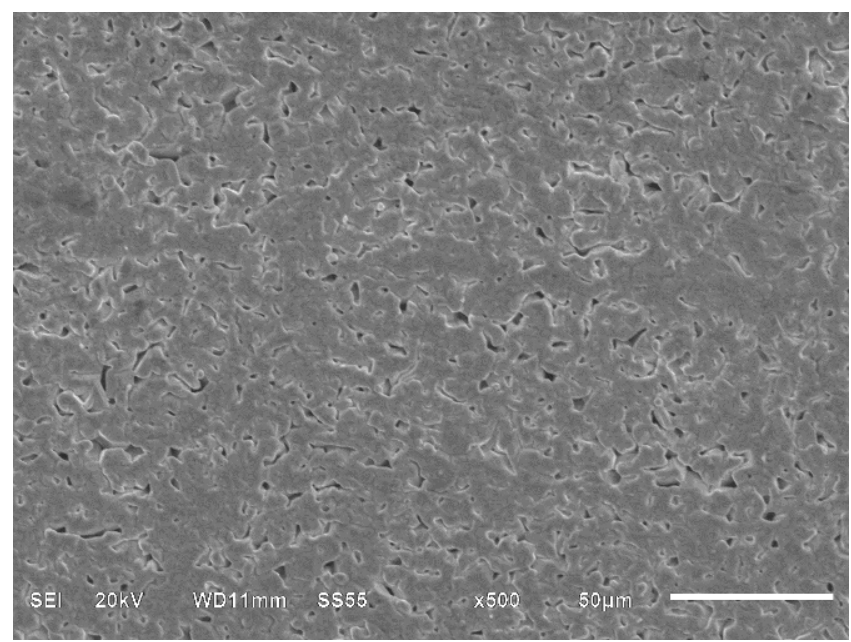

Figure 9. SEM images of electrolytic product in the condition of $50 \mathrm{~g} / \mathrm{L} \mathrm{Sn}(\mathrm{IV})$ ion and $2 \mathrm{~h}$ with flow flux $200 \mathrm{~L} / \mathrm{h}$ by using current density $400 \mathrm{~A} / \mathrm{m}^{2}$ (the other side of electrolytic product).

As shown in Figure7, the photo shows the surface of the electrolytic product. The electrolytic product's surface is smooth, brilliant and luster. That means the electrolytic product may have a good quality.

As shown in Figure8 9, SEM results illustrate that the surface microstructure is very compact, and the surface is smooth. The results also illustrate that the electrolytic product is of good quality. The cyclone electrowinning is a good metehod to recover tin from simulated leaching solution.

\section{CONCLUSIONS}

In this work, the performance of cyclone electrowinning on extraction of tin from simulated leaching solution was investigated. The results showed that $\mathrm{Sn}$ (II) could be extracted as sponge tin with cyclone electrowinning. Sn(IV) could be extracted as tin plate. As the concentration of tin chloride solution is lower, the current efficiency is lower and the quality of electrolytic product is poorer. On the condition of $\mathrm{Sn}(\mathrm{IV})$ concentration of $50 \mathrm{~g} / \mathrm{L}$, operation time of $2 \mathrm{~h}$, flow flux of 200 $\mathrm{L} / \mathrm{h}$ and current density of $400 \mathrm{~A} / \mathrm{m}^{2}$, the current efficiency was more than $90 \%$ and the electrolytic 
product was of high purity which contains $99.5 \%$ tin. Cyclone electrowinning was proved to be an effective way to extract tin from simulated leaching solution

Cyclone electrowinning is a new method to recover tin from leaching solution. However, both of how to get higher qulity of electrolytic product and how to improve current efficiency constantly should be further studied.

\section{ACKNOWLEDGEMENTS}

This work was completed with funding provided by national international cooperation project (2014DFA90920). We also appreciate that Zhejiang Kefei technology Co, Ltd provides the cyclone electrowinning equipment.

\section{REFERENCES}

[1]. Z.G.Kuang, C.Y.Huang, J. Shen, and L. Lu. Study on the new process of tin recovery in lead smelting and its production practice. Yunnan Metallurgy(2014),43(1),50-57.

[2]J . K. Wang, and G . L . Feng: Research and development of the continuous pressure acid leaching technology for the pretreatment of copper anode slime. Engineering Sciences(2009), 5.

[3] Y. Kilic, G.Kartal, and S.Timur: An investigation of copper and selenium recovery from copper anode slimes. International Journal of Mineral Processing (2013), 124, 75-82.

[4] Y. G. Li: Study on Hydrometallurgical Processing for Copper-bearing Anode Mud (I). Selective Leaching of $\mathrm{Cu}$, Se and Te Hydrometallurgy of China (2000), 1, 011.

[5] B. Dönmez, F. Sevim, and S. Colak: A study on recovery of gold from decopperized anode slime. Chemical engineering \& technology (2001), 24(1), 91-95.

[6] Z. Y. Hu, and X.W. Xia: The vortex electrolytic technology from copper recovery of copper and zinc in zinc ash study. Journal of Chemical Cngineering and Equipment(2011), 11, 68-71.

[7] Z.Y. Hu, and X.W. Xia: Production test of recovery copper use vortex electrolytic technology from high zinc manganese solution. Journal of Chemical Engineering and Equipment(2012), 1, 102104

[8] T. Deng. Vortex electrolytic technology and its applicat- ion. Journal of Nonferrous Metals in the World(2012), 12, 34-37.

[9] X.Y. Guo, W.T.Shi, D.Li, and Q.H.Tian. Recovery of copper and nickel from electroplating sludge by cyclone electrowinning, The Chinese Journal of Nonferrous Metals(2010), 20(12),24252430.

[10] Y.U. Kim, H.W. Cho, H.S. Lee, J.C. Lee, K.L. Rhee, H.J. Sohn, and T. Kang. Electrowinning of palladium using a modified cyclone reactor, Journal of Applied Electrochemistry(2002), 32(11), 1235 . 